\title{
Surgical treatment of axillary hyperhidrosis by suction-curettage of sweat glands"
}

\author{
Rebeca Maffra de Rezende ${ }^{1}$
}

Flávio Barbosa Luz ${ }^{1}$

DOI: http://dx.doi.org/10.1590/abd1806-4841.20142873

\begin{abstract}
Suction curettage is a dermatologic surgery technique for the treatment of axillary hyperhidrosis, which is becoming more popular. Objective: The purpose of this study is to describe the current technique of removal of axillary sweat glands, and evaluate its efficacy and safety. Conclusion: Suction-curettage of sweat glands is a minimally invasive surgical technique that is easy to perform, safe, has high rates of success and relatively few side-effects. It is generally well tolerated by patients and requires shorter time away from daily activities, when compared with other surgical modalities.
\end{abstract}

Keywords: Curettage; Hyperhidrosis; Lipectomy

\section{INTRODUCTION}

Hyperhidrosis is a common, underdiagnosed and undertreated disease. It is characterized by the secretion of sweat that exceeds the normal physiological needs of the body in order to regulate body temperature, and may significantly compromise the quality of life of affected patients. ${ }^{1-4}$ Studies on quality of life reveal that the negative effects of hyperhidrosis are comparable to those of conditions such as severe psoriasis, end-stage renal failure, rheumatoid arthritis and multiple sclerosis. ${ }^{5}$

Hyperhidrosis may be classified as primary (idiopathic) or secondary; generalized (involving the whole body) or focal (involving specific body sites). ${ }^{6}$

Primary hyperhidrosis is idiopathic and focal. Areas of excessive sweat production include the armpits, hands, feet and face. Affected individuals experience limitations at work, in social interaction, and in physical and leisure activities. The condition also causes psychological and relationship disorders which substantially compromise the patient's life. ${ }^{6}$ It may also lead to a large variety of secondary medical conditions such as bacterial or fungal overgrowth, muscle cramps, eczematous dermatitis, among others. ${ }^{7} \mathrm{Up}$ to two thirds of patients report a positive family history, which suggests that a genetic predisposition may exist. ${ }^{8}$

Secondary hyperhidrosis can be either generalized or focal, and results from an underlying condition such as endocrine, neurological, and infectious disorders, among others. ${ }^{2}$

\section{ASSESSMENT}

Some criteria are recommended for the diagnosis of primary focal hyperhidrosis. Excessive, visible and focal sweat secretion, with at least six months of duration and no apparent cause, should happen together with at least two of the following characteristics: relatively symmetrical and bilateral; substantial enough to impair daily activities; at least one episode per week; onset before twenty-five years of age; positive family history; and interruption of focal sweating during sleep. ${ }^{9}$

Currently, there are several (subjective and objective) ways to assess the degree of impairment of the disease. The Dermatology Life Quality Index (DLQI) and the scale of severity of hyperhidrosis are two widely accepted questionnaires for the assessment of the impact of disease on quality of life of patients.

Minor's starch-iodine test is an objective way to assess the extent and distribution of the disease, as well as the indirect iodine-starch test. However, these tests do not provide any indication of the severity of the condition..$^{8,10,11}$ For the conduction of these tests, the axilla should be clean, dry and hairless. In the Minor's starch-iodine test, an alcoholic solution of iodine is applied to the axillary skin. Once the solution has dried, the area is dusted with a thin layer of starch powder. When sweat is produced, it comes in contact with the two substances, generating a black- bluish to violet precipitate, and, hence, a positive test result. Vorkamp et al $(2010)^{10}$ suggest the use of a $3.5 \%$ alcoholic solution of iodine, as well as Swinehart (2000). ${ }^{12}$

Received on 16.06.2013.

Approved by the Advisory Board and accepted for publication on 05.09.2013.

$*$ Study conducted at the Hospital Universitário Antônio Pedro - Universidade Federal Fluminense (HUAP-UFF) - Niterói (RJ), Brazil.
Conflict of interest: None

Financial Support: None

Universidade Federal Fluminense (UFF) - Niterói (RJ), Brazil.

(C2014 by Anais Brasileiros de Dermatologia 
To perform the indirect test, a standard A4 paper sheet is premixed with non-pulverized crystals of iodine, and kept in a sealed vial for 5 days (1g of pure iodine to 50 sheets of paper). The sheet is then placed in the axilla for 1 minute. Hyperidrotic areas will mark the sheet with a blue-violet coloration. In most cases, the axillary sweat glands are concentrated in a central, circular or oval area, of approximately 4 to 5 centimeters. However, peripheral glands may also be found. ${ }^{12}$

Gravimetric test, ninhydrin test and VapoMeter may be used for a quantitative evaluation. ${ }^{13}$ However, objective methods for the visualization or weighing of sweat may, eventually, be disappointing, since the sweat rate fluctuates over time, and may even be completely absent at the time of consultation, even in patients without treatment. ${ }^{14}$

Although a standard definition for excessive sweating has yet to be established, Cohen et $\mathrm{al}^{15}$ (2007) and Solish et $\mathrm{al}^{16}$ (2008) believe that, in practice, any sweating that significantly interferes with daily life of patients (physically or psychologically, in the social or occupational sphere) should be considered abnormal.

It is important to exclude secondary causes (infections, malignancies, drugs, neurological, metabolic and endocrine disorders) before the diagnosis of primary hyperhidrosis is established. This disorder can occur at any stage of life. However, the mean age at the time of onset of disease depends on the site involved. Axillary onset usually occurs during adolescence. ${ }^{9}$

\section{THERAPEUTIC OPTIONS}

Although the etiopathogenesis of hyperhidrosis remains poorly understood, its effector pathway is well known. The various treatments affect different points of this pathway, as shown in chart 1 .

Several therapeutic options are available for the treatment of axillary hyperhidrosis: topical medications, systemic medications, iontophoresis, botulinum toxin and various surgical procedures. Each case must be evaluated separately, considering the severity and extent of the clinical condition, as well as the advantages and disadvantages of each method. We should always keep in mind that the treatment of axillary hyperhidrosis should follow a step-by-step strategy, beginning always with the use of conservative methods.

Atkins et al (2002) believe that the goal of treatment should be to reduce the amount of sweating to acceptable levels for the patient. ${ }^{17}$ The authors emphasize the importance of understanding the motivation and expectations of patients before choosing a treatment plan. They should be advised about possible complications and be aware of the limitations of all therapeutic options (clinical or surgical).

Coelho et al (2002) suggest that psychological and psychotherapeutic treatment can help, although they are palliative in nature. Therefore, they should be used in patients with exacerbated emotional component or with psychological or psychiatric diseases. ${ }^{18} \mathrm{~A}$ review conducted by Macía et al (2010) identified biofeedback and psychotherapy techniques as having limited efficacy. According to the authors, these techniques have long duration, demand excessive dedication and perseverance from patients, and have only provide uncertain results so far. ${ }^{19}$ However, it is important to note that, although the emotional stimulus is necessary for primary hyperhidrosis to occur in affected patients, it is not a psychological disease but rather a physiological disorder. ${ }^{20}$

CHART 1: Sites of action of therapies for axillary hyperhidrosis
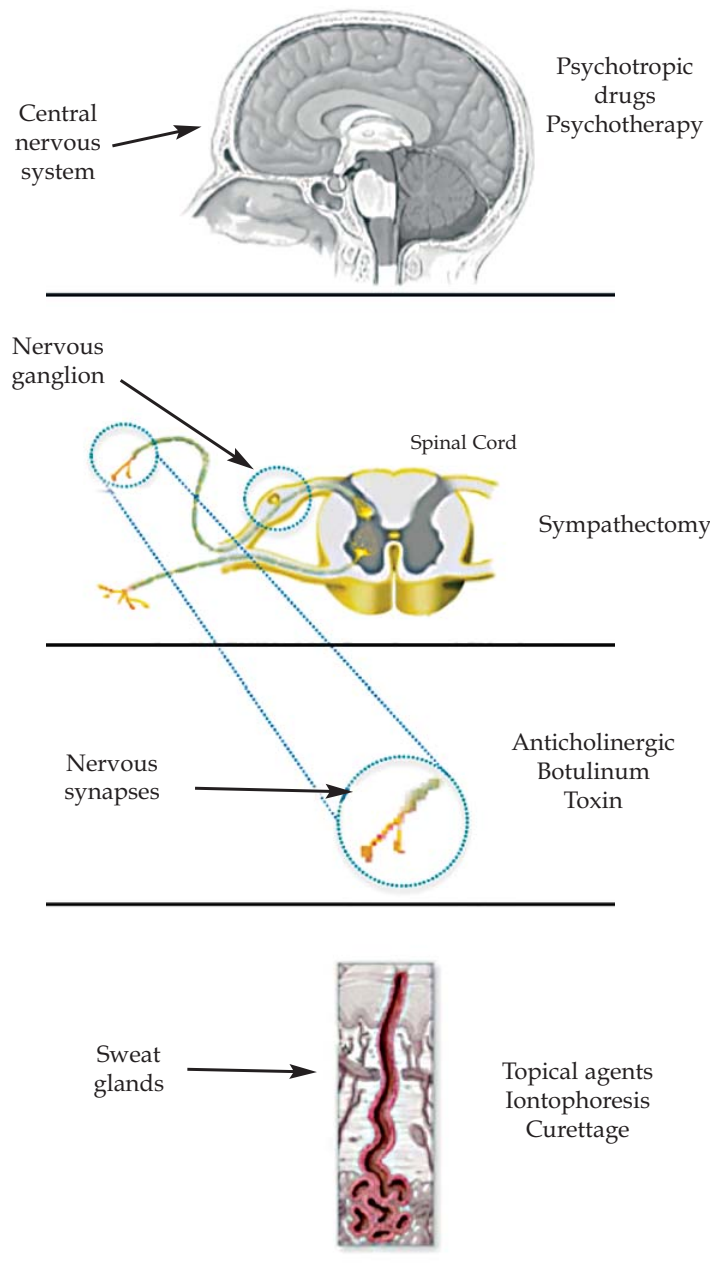


\section{CLINICAL TREATMENT}

Topical medications are usually easy to apply. However, they can cause skin irritations, have short duration of effect and are not very effective in severe cases. Nonetheless, due to its safety and reasonable effectiveness, topical therapy is considered the first line of treatment in most cases of axillary hyperhidrosis. Aluminum chloride is the most commonly used agent. The recommended initial concentration is 10$15 \%$, and it may be increased up to $35 \%$ in ethyl alcohol. ${ }^{1,8,10}$ Although its mechanism of action is not fully understood, it is believed that it blocks the distal acrosyringium, leading to functional and structural degeneration of the eccrine acini. ${ }^{21}$

Iontophoresis is a procedure that involves a complex process of ion transport through the skin by using galvanic current. ${ }^{22}$ However, it is difficult to be performed in the axilla and often causes irritation. ${ }^{8}$

Systemic anticholinergics inhibit sweating by competitive blocking of muscarinic receptors near eccrine sweat glands. However, its use is quite limited due to the side effects caused. ${ }^{23}$ In any case, evidence is lacking to prove the safety and efficacy of systemic anticholinergic agents for the treatment of axillary hyperhidrosis. These medications should only be considered to be used in severe cases, since the dose necessary to achieve relief of symptoms often results in complications and side effects such as xerostomia, palpitations, mydriasis, cycloplegia, postural hypotension, dizziness, dyspepsia and vesico-intestinal dysfunction, among others. ${ }^{8,24,25}$

\section{BOTULINUM TOXIN}

Botulinum toxin is considered a very effective and safe therapy. It has fast onset of action, high rate of patient satisfaction, and relatively few side effects. ${ }^{26,27}$ The application of $1 \mathrm{U} / \mathrm{cm}^{2}$ of botulinum toxin type A (50 to $100 \mathrm{U}$ per axilla) is recommended, depending on the response of the patient and the affected surface area. ${ }^{8}$ In a study, Swartling et al (2001) measuered the quality of life (DLQI) of patients undergoing treatment with botulinum toxin type A. They concluded that it improves the quality of life in patients with severe focal hyperhidrosis. ${ }^{14}$ However, its effect lasts for 6-8 months, multiple applications are required, and it is expensive, not being a viable option for many patients. Thus, because patients usually wish to achieve a permanent reduction in sweating, its benefits are limited. ${ }^{28}$

\section{SYMPATHECTOMY}

The transthoracic sympathectomy, currently preferably performed by endoscopy, seems to be effective in many cases. Total or partial removal, or disconnection of the T3-T4 thoracic ganglia is per- formed for the treatment of axillary hyperhidrosis. ${ }^{18,19}$ Unfortunately, it involves a large number of possible complications, such as arterial bleeding, bleeding from intercostal veins, hemopericardium, pleural effusion or adhesion, peripheral nerve injuries, gustatory sweating, complete or incomplete ClaudeBernard-Horner syndrome, neuralgia, hemothorax, pneumothorax, subcutaneous emphysema, chylothorax, and compensatory sweating. ${ }^{11,8,29,30}$ Although the majority of these complications is rare, compensatory sweating is a relatively common side effect of sympathectomy, with occurrence rates ranging from 60 to $90 \%$ in some series. ${ }^{31}$ The most commonly affected sites are the back, abdomen, thighs and chest. ${ }^{19,32}$ It is often considered by patients to be worse than the initial clinical picture that led them to seek surgical treatment. It is considered the main cause of dissatisfaction in many studies. ${ }^{33}$ Ninety -eight percent of patients with palmar hyperhidrosis achieve a complete and immediate anhidrosis, with low rates of recurrence. However, axillary hyperhidrosis does not respond as well to this method of treatment as palmar hiperhydrosis. ${ }^{29}$ Therefore, currently, endoscopic transthoracic sympathectomy is not considered a first-line therapy for focal hyperhidrosis strictly limited to the axilla. ${ }^{34}$

Most patients with severe localized hyperhidrosis need to consider surgery or botulinum toxin application as treatment options. ${ }^{35}$

However, Field (2003) questions the use of botulinum toxin over suction curettage in tumescent anesthesia, since the latter has shown to have remarkable advantages, to be safe and usually curative. ${ }^{36}$ The use of the toxin would sentence the patient to a lifetime of medical expenses, whereas suction curettage is performed in a single surgical intervention and has reasonable expectations of being curative.

Bechara et al (2007) argue, however, that if conservative treatment options are not effective, the next decision-making stage should be carried out together with the patient. The advantages and disadvantages of each method should be discussed, without favoring one technique as the general therapy of choice. ${ }^{11}$ The authors point out that, in these cases, doctors would find themselves at a crossroads. On one hand, they have the option of using botulinum toxin, a technique that is easy and effective, but also costly and of temporary effect. On the other hand, there is the option of using minimally invasive surgery, which requires more time and effort, and results in higher complication rates than the use of botulinum toxin. Nevertheless, surgery offers a potential for permanent reduction of hyperhidrosis, which is, in the authors' experience, the most frequent request from patients.

Numerous surgical techniques have been described for the removal of axillary sweat glands. 
However, it was only after the advent of minimally invasive techniques (e.g., curettage, liposuction, laser, ultrasonic surgical aspiration, electrosurgery, cryosurgery, suction-curettage) that its use became more widespread, due to their low complications rates, high success rates, fast recovery of patients and minimal scarring. ${ }^{37-54}$ Key factor is the removal of the sweat glands that are responsible for the condition with the least possible trauma. ${ }^{55}$

\section{MINIMALLY INVASIVE SURGICAL TREAT- MENT}

Patients increasingly wish for a safe procedure with very few side effects, lower complication rates and that keeps them the shortest possible time away from daily activities.

Local surgical treatment of axillary hyperhidrosis aims at eliminating the largest possible number of eccrine sweat glands in that region, while preserving, as much as possible, the normal aesthetic appearance of the axilla and mobility of the arm. ${ }^{29}$

Several surgical techniques have been developed and modified over the years. Bisbal et al (1987) ${ }^{56}$ divide the most important surgical techniques into three types: i) methods that only remove the subcutaneous tissue without excision of skin; ii) en bloc resection of the subcutaneous tissue and overlying skin; iii) en bloc excision of a small part of the central axillary region with removal of subcutaneous tissue in adjacent regions. ${ }^{56-67}$

However, with the emergence of new minimally invasive treatment options, Bechara et al (2007) ${ }^{68}$ suggest that type I surgeries should be divided into IA and IB. This division aims at distinguishing between two techniques: superficial liposuction and suction curettage. In the first, there is only the removal of subcutaneous tissue, whereas in the second there is the removal of subcutaneous and deep dermal tissues (Chart 2). There are also differences in the efficacy of these two techniques. Suction curettage shows a more significant reduction of sweat rates than superficial liposuction. ${ }^{34}$

Minimally invasive techniques offer several advantages such as reduction of the infection risk, reduction of postoperative pain, shorter recovery time and reduced scarring, when compared to traditional surgical methods. However, the small operative field used to perform these procedures requires great skill by the surgeons. ${ }^{69}$

\section{THE SUCTION CURETTAGE TECHNIQUE (IB - Bisbal/Bechara)}

The treatment of axillary hyperhidrosis by surgical removal of the sweat glands consists in the removal of eccrine, apocrine and apo-eccrine glands of the deep dermis and subcutaneous cellular tissue of this region (Figure 1 and Chart 3). Numerous variations of this technique exist.
ChART 2: Minimally invasive surgical techniques

TYPE IA: Remove the subcutaneous cellular tissue (SCCT) without excision of the skin (superficial liposuction)

TYPE IB: remove the SCCT and deep dermis without excision of the skin (curettage / suction)

TYPE II: En bloc resection of the SCCT and overlying skin TYPE III: En bloc excision of a small part of the central axillary region, and removal of the SCCT of the adjacent area
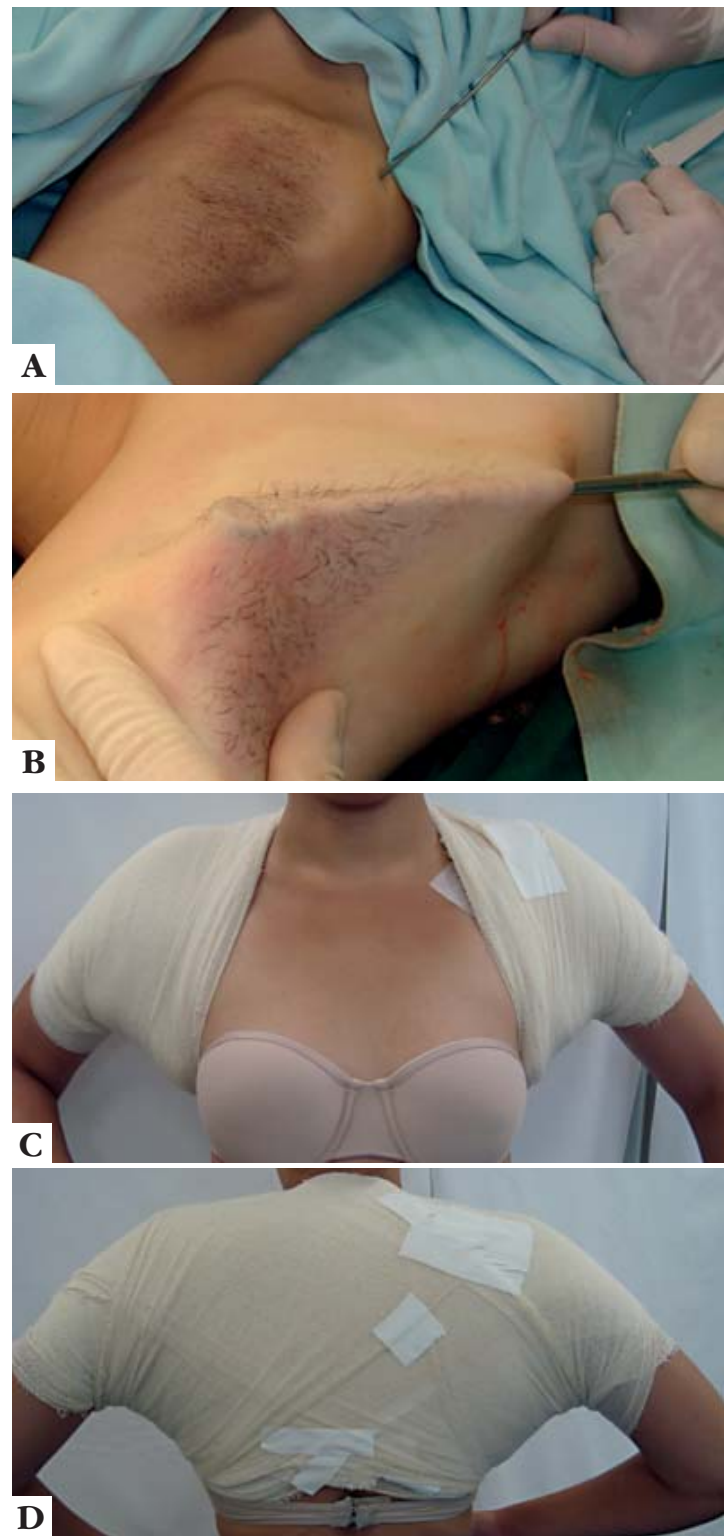

FIGURE 1: Removal of axillary sweat glands by suction-curettage. A: tumescent anesthesia; B: removal of the sweat glands by inverted curettage; $\mathbf{C}$ and $\mathbf{D}$ : compressive bandage 
CHART 3: Step-by-step explanation of the removal of axillary sweat glands by suction-curettage

1- Posicioning of the patient
2- Asepsis and antisepsis
3- Inicial local anesthetic infiltration
4- Incision
5- Introduction of the infiltration cannula
- Tumescent Anesthesia (Figure 1A)
- Back-and-forth movements for subdermal tunneling
6- Removal of glands by inverted curettage (Figure 1B)
7- Suction (dermal and subcutaneous cellular tissue) - optional
8- Sutures
9- Compressive bandage (Figure 1C and 1D)

The procedure consists of two main parts: dissection of the dermis of the underlying subcutaneous cellular tissue, followed by the removal of the sweat glands of the deep dermis and dermis/ hypodermis junction. ${ }^{70}$

The procedure is currently performed in outpatient settings, with tumescent anesthesia.

The area to be treated generally extends from 1 to 2 centimeters beyond the area of hair. However, the starch-iodine test can be performed before surgery to mark the affected area and avoid the occurrence of residual areas of hyperhidrosis. Some authors prefer shaving the axillary hair 2 to 3 days before surgery. ${ }^{71}$ Others would rather keep them, because they facilitate the visualization and demarcation of the area to be treated during the procedure, and serve as a parameter for its interruption. ${ }^{72}$

Patients are placed in the supine position with their arms abducted at a $90^{\circ}-135^{\circ}$ angle to expose the axilla. Excessive abduction should not be performed to avoid brachial plexus injury. ${ }^{73-75}$

For surgical access, two to three small incisions are made outside the area to be curetted. ${ }^{34}$ Such incisions are made at different sites according to the surgeon's preference: in the superomedial aspect of the axilla, at the anterior and distal edges, at the superior inner region of the arm, and at the central portion of the axilla. ${ }^{76-78}$

Subsequently, a volume of $100-500 \mathrm{ml}$ of tumescent solution is infiltrated, as superficially as possible, into the pre-marked area of each axilla, creating a "peau d'orange" effect in the overlaying tissue. ${ }^{12}$, ${ }^{71,73,77}$ Although the standard formula for tumescent anesthesia is $1000 \mathrm{ml}$ of normal saline, $50-100 \mathrm{ml}$ of $1 \%$ lidocaine, $1 \mathrm{ml}$ of 1:1000 epinephrine, and $12.5 \mathrm{ml}$ of sodium bicarbonate, there are numerous variations of the formula used by different authors. ${ }^{79}$ Wollina et al $(2008)^{71}$, for example, use a solution composed of 1000 $\mathrm{ml}$ of Ringer's solution, $50 \mathrm{ml}$ of prilocarpine and 1 $\mathrm{ml}$ of 1:1000 epinephrine solution in their study. This solution minimizes bleeding, makes dissection easier and reduces ecchimosis. ${ }^{80}$ The prolonged analgesic effect of lidocaine tissue deposits ensures an almost painless postoperative period. ${ }^{81}$ The expansion of the soft tissues of the axilla minimizes the risk of injury to the brachial plexus. ${ }^{82}$ It also has the advantage of eliminating the risks involved with general anesthesia, the use of intravenous sedation and narcotic analgesics. ${ }^{83}$ However, it is important that the solution is prepared shortly before surgery, because adrenaline does not remain stable for long periods. ${ }^{84}$ The use of small diameter infusion cannulas is important for the comfort of the patient. ${ }^{49}$

After bleaching of the region, subcutaneous tunnels are created by sharp dissection, in a back-andforth movement, in order to separate the dermis from the subcutaneous tissue. The subcutaneous sweat glands are thus mobilized. Subsequently, a Cassio cannula (or curette) for suction-curettage is inserted in order to perform the dermal curettage.

Suction of the removed tissue can be performed manually or by using a device. In the manual vacuum suction, a syringe is coupled to the cannula, which is inserted into the tissue to be removed before the plunger is withdrawn. A mechanical lock to hold the plunger open is necessary. However, this system does not provide a continuous deep vacuum. A disadvantage is that the vacuum may be lost if the cannula is accidentally partially withdrawn when suctioning close to the incisions site. If this occurs, the air must be removed from the syringe before reuse. When a mechanical suction system is chosen, the cannulae is connected to a collection bottle through a tube. The tissue mobilized by the cannulae is brought to the receptacle by means of a collecting system, using negative pressure generated by a vacuum pump. ${ }^{85}$

The size of the cannula and its opening, plus the amount of vacuum applied and the velocity of the stroke of the cannula directly affect the amount of tissue removed. ${ }^{85}$

The surgeon's non-dominant hand can assist in the procedure by compressing the overlying skin. ${ }^{73}$ One must be careful when performing curettage around the incision sites because the subcutaneous tissue near the incisions may not be appropriately removed with liposuction alone. ${ }^{86}$

Rho et al $(2008)^{73}$ perform copius irrigation and meticulous hemostasis at the end of the procedure, and then close the surgical incisions. They suggest the use of anchor sutures in the area treated with aggressive liposuction and curettage, since this would reduce the formation of hematomas.

Dressing can be done with antibiotic ointment. ${ }^{81}$ Some authors provide prophylactic antibiotic therapy to patients before surgery. ${ }^{34}$

There are reports on the use of arthroscopic shavers for the accomplishment of the procedure. 
Such instruments have a double cannula structure. The inner cannula is used for rotation, functioning as a continuous curette. The outer cannula is used to protect the epidermis from direct damage during curettage and liposuction. ${ }^{74}$

When an arthroscopic shaver is used to perform the procedure, it is positioned in the axilla after the dermis and the subcutaneous cellular tissue have been dissected with a scissor. Tunneling is performed before the activation of the blade or the suction device. The scraper blade should only be turned on in the withdrawal phase, and the device should not be passed more than once or twice in the same region..$^{75}$ The scraping tip should always be facing up in order to avoid damage to the nerves and deep vessels. A suction tube is connected to the handle of the shaver, in order to allow the rapid removal of the curetted tissue. ${ }^{80}$

The number of rotations per minute of the inner cannula varies in different studies. Lee et al $(2005)^{72}$ indicate that the system should be adjusted to maintain the inner cannula at $1500 \mathrm{rpm}$, in the oscillatory mode. Wu et al (2009) $)^{80}$ used it at 2500rpm, while Chern et al $(2010)^{74}$ would rather have it at $500 \mathrm{rpm}$. Arneja et al $(2005)^{75}$ suggest that the suction device is set to $50 \mathrm{mmHg}$.

Larson et al (2010) ${ }^{13}$ suggest that an assistant physician should perform manual traction to stabilize the axillary skin, both during tissue dissection with scissors and during curettage itself, in order to prevent skin perforations.

\section{COMPARATIVE ANALYSIS OF TECHNIQUES IA AND IB (BISBAL/BECHARA)}

A study conducted by Beer et al $(2006)^{87}$ demonstrated that the majority of all types of sweat glands (eccrine, apocrine and apo-eccrine) of the axilla of adult Caucasians is located in the subcutaneous cellular tissue, at the interface with the dermis, and not in the dermis itself. This finding suggests the optimization of type I surgery, with the abandonment of more radical surgical techniques (types II and III), which have a higher infection rate and result in large unsightly scars. However, the authors emphasize that the success of type I surgeries depends on the removal of the sweat glands of the dermis/subcutaneous interface to the point that the axillary tissue becomes similar to a total skin graft.

Tsay et al $(2001)^{88}$ conducted a study comparing the techniques of liposuction and curettage associated with liposuction to treat osmidrosis. The results showed that the second technique is preferred over liposuction alone. Among patients treated with liposuction, $10 \%$ were satisfied, $70 \%$ were partially satisfied and $20 \%$ dissatisfied. After treatment with curettage and suction, $80 \%$ of patients were satisfied and
$20 \%$ were partially satisfied.

In a study conducted by Grazer et al $(1992)^{85}$ to analyze the use of liposuction for treatment of hyperhidrosis, a 30\% recurrence rate was found. Although this method have many advantages - such as small wounds, short recovery periods, low complication rates and inconspicuous scars -, some of the sweat glands are firmly attached to the dermis and are hardly entirely removed with this type of procedure.

With the performance of superficial liposuction alone, it would be impossible to eradicate all subcutaneous glands, since a considerable force would be required for the disruption of the glands from their ducts. ${ }^{41,87}$

Histopathological analyzes performed on three patients by Park and Shin $(2001)^{89}$ have shown that there is an insufficient removal of sweat glands when blunt liposuction cannulae are used for scraping the dermis. Thus, whenever the curettage is performed, cutting instruments are necessary to allow the effective removal of sweat glands that are located in the deep dermis. ${ }^{34}$

In a study published in 2008 , Bechara et $\mathrm{al}^{78}$ confirmed, through histopathological analysis of the material aspirated during surgery, that curettage with liposuction is effective in removing sweat glands. Normal or destroyed glands were found in the material of all patients, and portions of connective tissue were found within the aspirate. This suggests that this method not only allows the removal of glands in subcutaneous fat but also enables curettage of the deep dermis. In all biopsies of patients who had undergone this method of treatment, histopathology demonstrated that the operated axillary skin was similar to a total skin graft. From a total of 15 patients assessed by this technique, 1 (one) showed only a slight reduction in the sweating rate. However, the authors concluded in this case that the procedure had not been performed in a sufficient or sufficiently aggressive way, since histopathological analysis revealed a large number of residual sweat glands.

The technique consisting of curettage and mechanical suction, performed with the use of arthroscopic shavers, would have the advantage of allowing a faster surgery, when compared to manual curettage. However, surgeons who are inexperienced in the use of the technique should beware of the possibility of perforation of the axillary skin. If the suction is too strong, the dermis could be strongly sucked against the blade. Bechara et al (2007) ${ }^{90}$ point out that a more extensive training would be necessary to avoid such perforations, when compared to other techniques such as curettage, superficial liposuction and liposuction curettage. The authors also highlight the high costs of the material needed. Thus, suction-curettage is a considerably more favorable method in terms of cost-benefit, and offers similar results. 
In a study for the treatment of osmidrosis, Lee et al $(2005)^{72}$ reported a reduction in cases of skin perforation with the use of a modified outer cannula. This outer cannula had a grid on its orifice in order to protect the dermis from the inner curette. The same authors suggest that a careful palpation of the axillary skin thickness is carried out, in order to avoid deep planes and consequent risk of vascular damage.

\section{THE CHOICE OF THE CANNULA}

To Bechara et al (2007), ${ }^{11}$ minimally invasive surgeries will only offer promising results if a strong resection of the glands at the dermis-subcutaneous interface is performed, leaving the skin looking like a total graft tissue. This area would have its blood supply from the surrounding skin, which has not been submitted to the procedure. ${ }^{70}$

Thus, cutting instruments would be necessary when performing curettage of the deep dermis, in order to effectively remove the sweat glands (Figure 2). ${ }^{74,77}$ The use of different cannulas with sharp surface has been described: liposuction cannulas, gynecologic cannulas, sharp spoons, cannulas specially designed for this purpose. However, the choice of the cannula to be used varies greatly among authors. In general, this choice is based on the surgeon's personal experience or on suggestions taken from isolated case reports. ${ }^{91}$

The Fatemi cannula has a 3-mm diameter and $20-\mathrm{cm}$ length. It has the ability of simultaneously performing suction and curettage. Its ability in removing both eccrine and apocrine glands has been already demonstrated..$^{77,92}$ However, Bechara et al (2007) ${ }^{93}$ criticize the small holes in its side, which often clog with dermal tissue, limiting an efficient curettage in the deep dermis. In addition, it has a very small diameter. Although the Fatemi cannula has cutting edges, it presents structural limitations that would hinder the achievement of enough pressure to reach the deep dermis when a more aggressive approach is required. Nevertheless, this cannula could be used at the begin- ning of the procedure for dissecting the dermis of the subcutaneous cellular tissue.

The Capistrano cannula is very similar to the Fatemi cannula, and also does not seem to offer the perfect mechanical properties for a radical resection of the glands. The scraping edges of its holes are only slightly elevated and the cannula is slightly sharp. ${ }^{11}$

Therefore, a rasping-type cannula would be more appropriate to perform a more aggressive procedure and consequently achieve higher curative rates. The Cassio cannula could serve that purpose, because it has a cutting edge and a large hole. However, additional care should be taken when using these cannulas alone. If used too aggressively, they can lead to skin necrosis.

Thus, Kim et al (2008) $)^{92}$ suggest the association of the Fatemi and Cassio cannulas as a solution to this problem. One cannula would complement the deficiencies of the other, improving the final result and reducing the risk of complications.

Bechara et al $(2008)^{94}$, however, do not recommend the combined use of two cutting devices in the same procedure. A study conducted by these authors had to be suspended due to complications in four patients, that were generated by the use of a combination of dermal curette and sharp rasping cannula. Such a combination would lead to extensive skin damage, impairment of the dermal vascular plexus, and no additional gains in the results.

In an article published in 2006 , Bechara et al ${ }^{34}$ compared the use of three different cannulas: one liposuction cannula with only 1 hole and a flattened tip; another cannula with three holes and a rounded tip; and the third cannula, especially created for curettage with liposuction, with 3 cutting holes and sharp rasps among the holes. Although all the 3 cannulas have led to a significant reduction in sweat rates, there was a greater reduction in the group in which the sharp cannula specially created for this purpose was used. In addition, patients operated with this cannula seemed to be more satisfied with the results. The authors
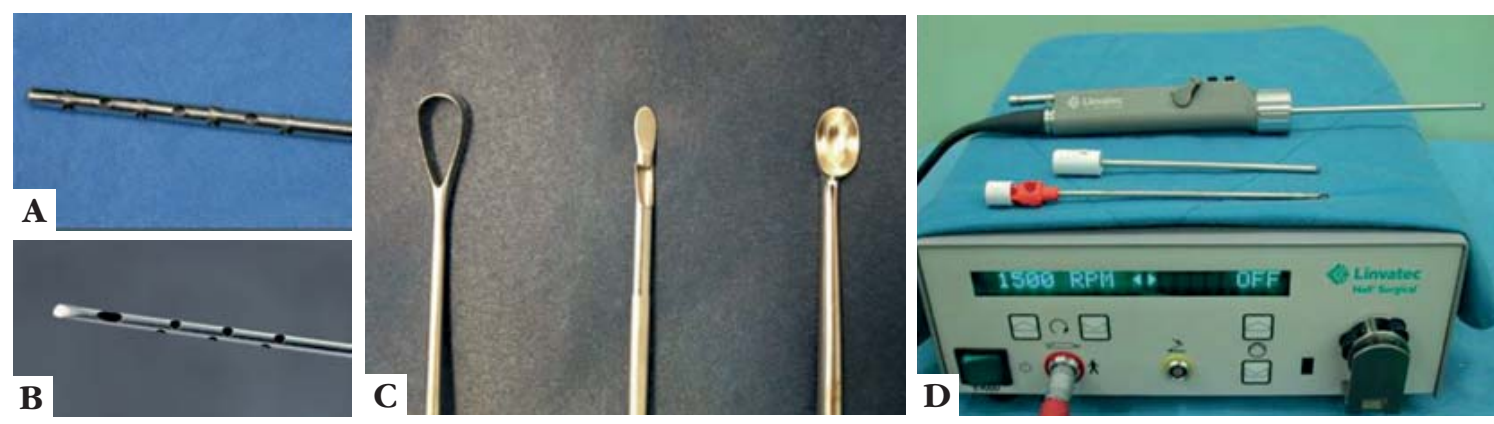

FIgURE 2: Instruments used for curettage (examples): A: Fatemi Cannula; ${ }^{77}$ B: Capistrano Cannula; C: Recamier gynecologic curette, Cassio cannula, Schroeder gynecological curette (from the left to the right); D: Arthroscopic shaver ${ }^{72}$ 
attributed this success to the fact that the special cannula had the sharp rasps among its holes. These would allow an aggressive scraping of the dermal tissue. The traditional liposuction cannulas would have a lower efficiency due to their own structure. Even those with more holes are not sharp.

Bechara et al (2007) ${ }^{91}$ believe that the slightly higher complications rate - found with the use of a more aggressive cannula - is acceptable, because the adverse effects are not permanent or severe, and are well accepted by most patients. The authors show, in this study, that a wider and more aggressive cannula has a significantly higher efficacy when compared to less aggressive cannulas.

\section{INTERRUPTION OF THE PROCEDURE}

Since patients are more interested in getting a positive result than concerned about having focal scars in hidden areas, Field (2003) ${ }^{95}$ suggests that surgeons do not hesitate to curette the region aggressively in an attempt to avoid minor scarring complications. According to the author, patients are always informed about the procedures and would rather have a more aggressive surgery as long as it is curative.

However, surgeons should be alert to the fact that curettage should be performed in such a way as to generate the best possible results with the fewest possible side effects (Chart 4 and Figure 3).

Field et al (2009) $)^{96}$ reported that, during curettage, the tension and tightness of the overlying skin is of great importance. Even more important is the force applied during the scraping movements, so that the surgeon knows when to stop the procedure.
Bechara et al (2007) ${ }^{97}$ give some intraoperatory, clinical clues indicating sufficient curettage: complete elevation of axillary skin from subcutaneous cellular tissue; slight lividity of axillary skin; 'skin to skin' rolling, showing that there is no more fat adhering to the dermis; palpable hair follicles during 'skin to skin' rolling; 'sipping' sounds caused by the cannula due to the axillary 'cavity', demonstrating complete dissection of the dermis and subcutaneous cellular tissue.

Rho et al $(2008)^{73}$ indicate as signals of sufficient curettage: skin thickness (skin becomes very thin and easy to pinch, as if it were a piece of clothing); and overlying skin coloration (skin becomes slightly violet-colored, which indicates significant damage to the dermal vascular plexus).

Seo et al $(2008)^{86}$ report that, at the end of the procedure, the skin is very thin, violet to pale-colored, with a few petechiae. They also add another signal that the procedure should be interrupted: visualiza-

CHART 4: Parameters for determining sufficient curettage

1- Skin thickness - thin and easy to pinch (Figure 2A)

2- Skin coloration - pale to violet; petechiae may be seen (Figure 2B)

3- Complete elevation of axillary skin from subcutaneous cellular tissue

4- 'Skin to skin' rolling, showing that there is no more fat adhering to the dermis

5- Palpable hair follicles during 'skin to skin' rolling;

6- 'Sipping' sounds caused by the cannula

7- Visualization of the skin being sucked through the holes of the cannula in use (Figure 2C)

8- Axillary hair can be easily detached when gently pulled by the surgeon. (Figure 2D and 2E)

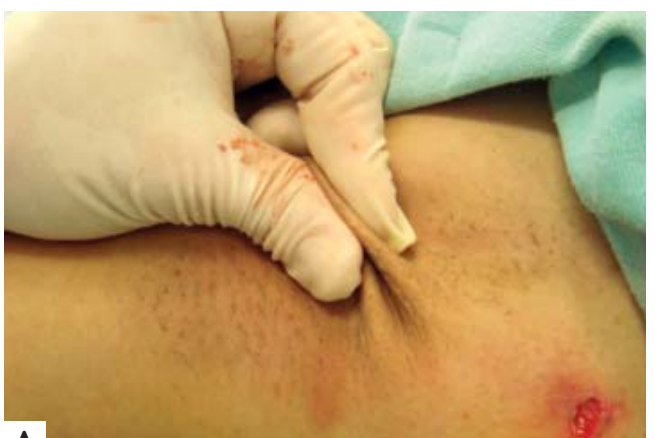

$\mathbf{A}$

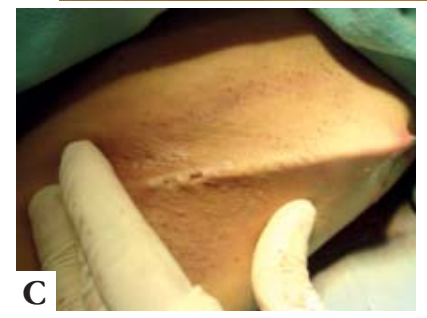

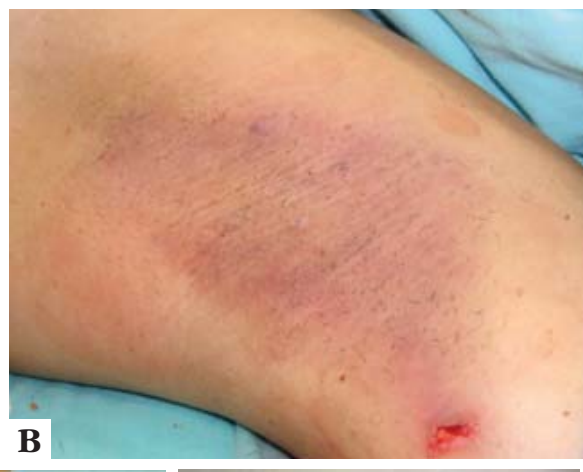

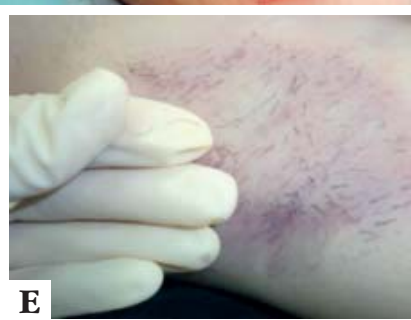

FiguRE 3:

Parameters used to indicate sufficient curettage: A: skin is thin and easy to pinch; B: violet skin coloration; C: skin sucked through the holes of the suction cannula; D and E: easy detachment of hairs when gently pulled by the surgeon 
tion of the skin being sucked through the holes of the cannula in use.

Liu et al $(2010)^{98}$ believe that the procedure should be performed until the axillary hair can be easily detached when externally pulled by the surgeon. Thus, the axillary hair should grow to a length of 2 to $4 \mathrm{~mm}$ before surgery.

Wu et al $(2009)^{80}$, in a study on osmidrosis, provide some tips for preventing skin necrosis when using arthroscopic shavers: 1) using an inner cannula with a toothless tip, to prevent skin breakdown or necrosis of the edge of incisions; 2) placing a grid on the tip of the outer cannula in order to reduce dermal damage; 3) keeping the scraping tip in motion during all procedures is important in order to prevent damage to the subdermal plexus, skin breakdown and necrosis of the edge of incisions; 4) keeping the arm abducted at an angle smaller than $45^{\circ}$ during the postoperative period (21 days) may reduce tension to the axillary skin, which contributes to poor circulation in the subdermal plexus or necrosis of the edges. The authors also indicate as parameters for the interruption of surgery: 1) direct visualization of the dermis with the aid of two retractors. The small incisions would serve as windows for the visualization of possible residual apocrine glands; 2) palpation of the treated area to check the thickness of the dermis. 3) endoscopic confirmation. This is useful to beginners, who could train palpation of the optimum thickness by using endoscopic confirmation. Arneja et al (2007) ${ }^{75}$ also state that the skin thickness should be evaluated by palpation during the entire procedure, which should be stopped when the glandular tissue is no longer palpable.

\section{OTHER CAUTIONS}

The axilla is a region of the body that is more prone to the formation of hematoma and seroma, due to the inability to properly compress the axillary cavity created by the surgical procedure during the initial postoperative period. ${ }^{75}$ Hematomas increase the risk of postoperative infections, delay healing and may lead to the formation of hypertrophic scars and irregularities on the skin surface. ${ }^{73}$ Therefore, after the procedure, large compressive bandages should be used for 2-3 days to prevent hematomas and seromas.

Patients should be advised to avoid abrupt movements of the arms (especially abduction and elevation movements) for 2 weeks. Strenuous physical exercise should be avoided for 1 month. ${ }^{86}$

Bienik et al (2005) ${ }^{81}$ suggest the introduction, three weeks after surgery, of local measures for prevention and improvement of subcutaneous fibrosis, such as: local heat, massage, gels or ointments containing heparin or flavonoids. Such measures should be maintained for three months after the procedure.

Chern et al (2010) ${ }^{74}$ conducted a study for the treatment of 30 patients with osmidrosis, in which they dissected the subcutaneous tissue prior to curettage and liposuction. The procedure was performed through cavities opened between the fibrovascular bands. There was a $93 \%$ rate of satisfaction. No cases of hematoma or skin necrosis were reported. The authors therefore recommend the careful preservation of subcutaneous fibrovascular cords during liposuction-curettage with the arthroscopic shaver, which would result in a more effective clinical response with fewer complications.

\section{COMPLICATIONS}

Although minimally invasive techniques have shown a relatively low complications rate, a variety of mild to moderate side effects (for the most part, temporary) has been reported. ${ }^{99}$ Possible complications include: hematomas, ecchymosis, seromas, superficial erosions of the skin, loss of local sensitivity, skin necrosis, infection, reduction in the number of hairs, fibrosis, formation of subcutaneous adherences, scars and recurrence of hyperhidrosis (Table 1).$^{100}$

Bechara et al (2007) ${ }^{101}$ describe the case of a patient who presented with bilateral seroma, a rare complication. The patient had previously undergone transaxillary surgery for breast enlargement, and presented many adhesions that could not be dissected only with a suction-curettage cannula, but had to be removed with the use of scissors. The authors propose that previous surgical interventions in the axillary region should be considered as a risk factor for a higher incidence of complications.

There has been a report of the occurrence of multiple epidermal inclusion cysts after liposuctioncurettage. $^{99}$ The authors believe that the extensive curettage of deep dermal layers would lead to damage to the pilosebaceous unit, with consequent trauma or occlusion of the excretory ducts. Such damage would also be the factor responsible for the partial alopecia of the axillary skin after surgery. Rho et al $(2008)^{102}$ suggest that the trauma would be associated with an abnormal repair of hair follicles, leading to the emergence of structures that are unable to produce hairs, but are capable of forming keratin.

\section{FINAL CONSIDERATIONS}

Axillary hyperhidrosis is not only an aesthetic problem, but a disabling and distressing disease. Suction-curettage is effective and can significantly improve the quality of life of patients. ${ }^{28}$

However, recurrences may occur after the procedure. Although the exact cause for this fact is not clearly understood, many theories have been suggest- 
TABLE 1: Complications assotiated to the liposuction-curettage method - correlation with the instruments used

\begin{tabular}{|c|c|c|c|c|}
\hline Reference & Surgical Method & Material & No. patients & $\begin{array}{l}\text { Complications / Side effects } \\
\text { (n patients) }\end{array}$ \\
\hline $\begin{array}{l}\text { Lee D, } 2006^{77} \\
\text { (Hyperhidrosis/ } \\
\text { Osmidrosis) }\end{array}$ & Liposuction-curettage & Fatemi Cannula & $\begin{array}{l}25 \text { (Analysis } \\
\text { of } 20 \text { ) }\end{array}$ & $\begin{array}{l}\text { Transient ecchymoses (not specified) } \\
\text { Local secondary infection ( } 2 \text { ) } \\
\text { Reduction in the number of hairs (20) }\end{array}$ \\
\hline $\begin{array}{l}\text { Kim, 200892 } \\
\text { (Hyperhidrosis/ } \\
\text { Osmidrosis) }\end{array}$ & Liposuction-curettage & $\begin{array}{l}\text { Fatemi + Cassio } \\
\text { Cannulae }\end{array}$ & 65 & $\begin{array}{l}\text { Transient ecchymoses (not specified) } \\
\text { Focal alopecia (2) } \\
\text { Partial elimination of osmidrosis (2) } \\
\text { Recurrrence of osmidrosis within } 1 \\
\text { year (2) } \\
\text { Scar (1) } \\
\text { Seroma (1) } \\
\text { Wound dehiscence (1) } \\
\text { Skin desquamation (2) } \\
\text { No improvement of hyperhidrosis (1) } \\
\text { Recurrence of axillary hyperhidrosis (1) }\end{array}$ \\
\hline $\begin{array}{l}\text { Wollina, 2008 } \\
\text { (Hyperhidrosis) }\end{array}$ & Liposuction-curettage & $\begin{array}{l}\text { Fatemi or Sattler } \\
\text { Cannula }\end{array}$ & 37 & $\begin{array}{l}\text { Mild hematoma (29) } \\
\text { Mild skin irritation near the suture (6) } \\
\text { Temporary hypoesthesia (21) } \\
\text { Partial recurrence (6) } \\
\text { Temporary, mild to moderate subcuta- } \\
\text { neous cords (4) }\end{array}$ \\
\hline $\begin{array}{l}\text { Seo, } 2008^{86} \\
\text { (Osmidrosis) }\end{array}$ & Liposuction-curettage & Fatemi Cannula & 43 & $\begin{array}{l}\text { Transient ecchymoses (40) } \\
\text { Focal skin necrosis (4) } \\
\text { Induration (3) } \\
\text { Hematoma/seroma (1) }\end{array}$ \\
\hline $\begin{array}{l}\text { Bieniek, } 2005^{81} \\
\text { (Hyperhidrosis) }\end{array}$ & Liposuction-curettage & $\begin{array}{l}\text { 3- to } 4 \text {-mm diameter } \\
\text { liposuction cannula }\end{array}$ & 15 & $\begin{array}{l}\text { Hematoma (2) } \\
\text { Recurrence of hyperhidrosis (4) } \\
\text { Transient fibrosis (3) } \\
\text { Necrosis (2) }\end{array}$ \\
\hline $\begin{array}{l}\text { Bechara, 2006 } \\
\text { (Hyperhidrosis) }\end{array}$ & Liposuction-curettage & $\begin{array}{l}\text { 1. liposuction cannula } \\
\text { with one hole } \\
\text { 2. liposuction cannula } \\
\text { with } 3 \text { holes } \\
\text { 3. sharp cannula especially } \\
\text { designed for liposuction- } \\
\text { curettage }\end{array}$ & 14 & $\begin{array}{l}\text { Hematoma }(6 / 6 / 8) \\
\text { Superficial skin erosion }(1 / 2 / 2) \\
\text { Formation of adherence }(3 / 3 / 4) \\
\text { Seroma }(1 \text { patient in the group using } \\
\text { the cannula with } 3 \text { holes) } \\
\text { Paresthesia }(6 / 7 / 8) \\
\text { Partial alopecia }(2 / 2 / 3)\end{array}$ \\
\hline $\begin{array}{l}\text { Chern, } 2010^{74} \\
\text { (Osmidrosis) }\end{array}$ & Liposuction-curettage & Arthroscopic shaver & 30 & $\begin{array}{l}\text { Surgical wound infection ( } 1 \text { axilla) } \\
\text { Mild to moderate ecchymoses ( } 28)\end{array}$ \\
\hline $\begin{array}{l}\text { Darabaneanu, 2008 } \\
\text { (Hyperhidrosis) }\end{array}$ & Liposuction-curettage & Cânula de 12 gauges & 28 & $\begin{array}{l}\text { Mild surgical wound infections }(4) \\
\text { Persistent hypertrophic scar with disfi- } \\
\text { gurement (1) }\end{array}$ \\
\hline $\begin{array}{l}\text { Arneja, } 2007^{75} \\
\text { (Hyperhidrosis) }\end{array}$ & Suction-curettage & Arthroscopic shaver & 50 & $\begin{array}{l}\text { Hypertrophic scar (1) } \\
\text { Recurrence (3) } \\
\text { Alopocia (1) } \\
\text { Infection (7) } \\
\text { Paresthesia (1) }\end{array}$ \\
\hline $\begin{array}{l}\text { Lee, } 2005^{72} \\
\text { (Osmidrosis) }\end{array}$ & Suction-curettage & $\begin{array}{l}\text { Arthroscopic shaver (E9005 } \\
\text { System, Linvatec Corporation, } \\
\text { Largo, Florida, USA) }\end{array}$ & 89 & $\begin{array}{l}\text { Hypertrophic scar (1) } \\
\text { Temporary hyperpigmentation (not } \\
\text { specified) } \\
\text { Temporary induration (not specified) }\end{array}$ \\
\hline
\end{tabular}


Continuation.

TABLE 1: Complications assotiated to the liposuction-curettage method - correlation with the instruments used

\begin{tabular}{|c|c|c|c|c|}
\hline Reference & Surgical Method & Material & No. patients & $\begin{array}{l}\text { Complications / Side effects } \\
\text { (n patients) }\end{array}$ \\
\hline $\begin{array}{l}\text { Bechara, 2008 } \\
\text { (Hyperhidrosis) }\end{array}$ & Liposuction-curettage & $\begin{array}{l}\text { Sharp rasping cannula } \\
\text { (Gaedigk GmbH, Bochum, } \\
\text { Germany) }\end{array}$ & 15 & $\begin{array}{l}\text { Hematoma (3) } \\
\text { Paresthesia (4) } \\
\text { Focal loss of hairs (9) } \\
\text { Subcutaneous fibrotic adhesions (8) } \\
\text { Seroma (1) } \\
\text { Skin erosion (3) } \\
\text { Necrosis (1) }\end{array}$ \\
\hline $\begin{array}{l}\text { Wu, 200980 } \\
\text { (Osmidrosis) }\end{array}$ & Suction-curettage & $\begin{array}{l}\text { Arthroscopic shaver (E9005 } \\
\text { System, Livatec Corporation, } \\
\text { Largo, FL) }\end{array}$ & 156 & $\begin{array}{l}\text { Hematoma (2) } \\
\text { Necrosis (10) } \\
\text { Transient paresthesia (5) }\end{array}$ \\
\hline $\begin{array}{l}\text { Park, 2001 } \\
\text { (Osmidrosis) }^{89}\end{array}$ & Suction-curettage & Suction cannula with one hole & 32 & $\begin{array}{l}\text { Recurrence of osmidrosis (15) } \\
\text { No complications }\end{array}$ \\
\hline $\begin{array}{l}\text { Larson, } 2011^{13} \\
\text { (Hyperhidrosis) }\end{array}$ & Suction-curettage & $\begin{array}{l}\text { Arthroscopic shaver (Stryker, } \\
\text { Kalamazoo, Michigan) }\end{array}$ & 45 & $\begin{array}{l}\text { Infection (1) } \\
\text { Hematoma (1) } \\
\text { Recurrence of symptoms (2) }\end{array}$ \\
\hline $\begin{array}{l}\text { Huang, 2010 } \\
\text { (Osmidrosis) }\end{array}$ & Suction-curettage & $\begin{array}{l}\text { Arthroscopic shaver (E9005 } \\
\text { System, Livatec Corporation, } \\
\text { Largo, FL) }\end{array}$ & 70 & $\begin{array}{l}\text { Epidermal cysts (2) } \\
\text { Scars (5) } \\
\text { Skin Hyperpigmentation (7) } \\
\text { New vitiligo lesions at the axilla (1) }\end{array}$ \\
\hline $\begin{array}{l}\text { Bechara, 2007² } \\
\text { (Hyperhidrosis) }\end{array}$ & Suction-curettage & Rasping cannula & 51 & $\begin{array}{l}\text { Ecchymoses (39) } \\
\text { Skin erosion (14) } \\
\text { Temporary formation of adherences } \\
\text { (11) } \\
\text { Seroma (7) } \\
\text { Dysesthesia (6) } \\
\text { Focal loss of hairs (4) }\end{array}$ \\
\hline $\begin{array}{l}\text { Seo, } 2008^{86} \\
\text { (Osmidrosis) }\end{array}$ & Suction-curettage & $\begin{array}{l}\text { Fatemi } \\
\text { Cannula }\end{array}$ & 43 & $\begin{array}{l}\text { Transient ecchymoses }(40) \\
\text { Focal skin necrosis }(4) \\
\text { Induration }(3) \\
\text { Hematoma or seroma }(1)\end{array}$ \\
\hline $\begin{array}{l}\text { Bechara, 200797 } \\
\text { (Hyperhidrosis) }\end{array}$ & $\begin{array}{l}\text { Suction-curettage } \\
\text { (2nd surgery) }\end{array}$ & $\begin{array}{l}\text { Sharp rasping cannula (Gaedigk } \\
\text { GmbH, Bochum, Germany) }\end{array}$ & 19 & $\begin{array}{l}\text { Superficial skin erosions (6) } \\
\text { Temporary paresthesia (4) } \\
\text { Seroma (2) } \\
\text { Temporary adherences (6) } \\
\text { Partial alopecia (3) }\end{array}$ \\
\hline $\begin{array}{l}\text { Rezai, } 2009^{84} \\
\text { (Hyperhidrosis) }\end{array}$ & Suction-curettage & 7-mm cannula & 168 & $\begin{array}{l}\text { Seroma (5) } \\
\text { Desquamation similar to scald buns in } \\
\text { the central axillary region ( } 25)\end{array}$ \\
\hline
\end{tabular}

ed, such as insufficient curettage and anatomical variations with large concentrations of sweat glands in the upper reticular dermis. Other hypotheses are: compensatory hyperfunction of the remaining sweat glands, and curettage performed in a wrong anatomical tissue layer. ${ }^{97}$ The findings from an endoscopic study conducted by Bechara et al (2006 $)^{103}$ shortly after suction-curettage suggest that performing the procedure in a very superficial level makes it virtually impossible to completely remove the sweat glands . This fact is corroborated by the findings of Lawrence et al (2006 $)^{67}$ that showed the presence of sweat glands in the lower portion of the skin. An average of 3-5 mm of its thickness was found to be occupied by glandular tissue.

Bechara et al (2009) ${ }^{104}$ evaluated 24 patients with recurrent sweating after performing minimally invasive procedures (liposuction and liposuction-curettage) using the starch- iodine test. The authors found three patterns of recurrence: circular, crescent and punctual at the site of the surgical incisions. These patterns indicate that surgeons focus mainly on the cen- 
TABLE 2: Results of the liposuction-curettage method

\begin{tabular}{|c|c|c|c|}
\hline Reference & $\mathrm{N}$ patients & $\begin{array}{l}\text { Follow-up } \\
\text { in months } \\
\text { (average) }\end{array}$ & Results \\
\hline $\begin{array}{l}\text { Lee, } 2006^{77} \\
\text { (Osmidrosis/ } \\
\text { Hyperhidrosis) }\end{array}$ & 25 & 10,7 & $\begin{array}{l}98 \% \text { of good to excellent in relation to the smell } \\
100 \% \text { of patients with hyperhidrosis (3) with excellent results }\end{array}$ \\
\hline $\begin{array}{l}\text { Seo, } 2008^{86} \\
\text { (Osmidrosis) }\end{array}$ & 43 & 15,8 & $72,1 \%$ of good to excellent \\
\hline $\begin{array}{l}\text { Boni, } 2006^{110} \\
\text { (Hyperhidrosis) }\end{array}$ & 63 & 24 & $\begin{array}{l}\text { - } 49 \text { satisfied patients } \\
\text { - } 11 \text { partially satisfied patients } \\
\text { - } 3 \text { dissatisfied patients }\end{array}$ \\
\hline $\begin{array}{l}\text { Tsai, } 2001^{88} \\
\text { (Osmidrosis) }\end{array}$ & 10 & Not mentioned & $\begin{array}{l}80 \% \text { of satisfied patients } \\
20 \% \text { of partially satisfied patients }\end{array}$ \\
\hline $\begin{array}{l}\text { Chern, 2010 } \\
\text { (Osmidrosis) }\end{array}$ & 30 & 10 & $\begin{array}{l}93 \% \text { from good to excellent } \\
7 \% \text { of reasonable results }\end{array}$ \\
\hline $\begin{array}{l}\text { Wollina, } 2008^{71} \\
\text { (Hyperhidrosis) }\end{array}$ & 37 & 48 & $\begin{array}{l}83,8 \% \text { of satisfied patients } \\
5,4 \% \text { of partially satisfied patients } \\
10,8 \% \text { of dissatisfied patients }\end{array}$ \\
\hline $\begin{array}{l}\text { Arneja, } 2007^{75} \\
\text { (Hyperhidrosis) }\end{array}$ & 50 & 28 & $\begin{array}{l}96 \% \text { of patient satisfaction } \\
-2 \text { dissatisfied patients (due to the occurrence of post-operatory infec- } \\
\text { tion, not due to recurrence) } \\
-3 \text { patients with mild recurrence }\end{array}$ \\
\hline $\begin{array}{l}\text { Lee, } 200572 \\
\text { (Osmidrosis) }\end{array}$ & 89 & 20 & $\begin{array}{l}\text { - Excellent in } 55 \text { patients }(61,8 \%) \\
\text { - Good in } 27 \text { patients }(30,4 \%) \\
\text { - Reasonable in } 7 \text { patients }(7,9 \%)\end{array}$ \\
\hline $\begin{array}{l}\text { Wu, 200980 } \\
\text { (Osmidrosis) }\end{array}$ & 156 & 16 & $\begin{array}{l}97,4 \% \text { of satisfaction } \\
\text { - } 144 \text { satisfied patients } \\
\text { - } 8 \text { partially satisfied patients } \\
\text { - } 4 \text { dissatisfied patients }\end{array}$ \\
\hline $\begin{array}{l}\text { Bechara, } 2007^{28} \\
\text { (Hyperhidrosis) }\end{array}$ & 51 & 9 & $96,1 \%$ of satisfied patients \\
\hline $\begin{array}{l}\text { Huang, } 2010^{100} \\
\text { (Osmidrosis) }\end{array}$ & 70 & 18,3 & $\begin{array}{l}\text { - } 24 \text { very satisfied patients } \\
\text { - } 41 \text { absolutely satisfied patients } \\
\text { - } 5 \text { satisfied patients }\end{array}$ \\
\hline $\begin{array}{l}\text { Bechara, } 2007^{97} \\
\text { (Hyperhidrosis) }\end{array}$ & 19 & 8 & $\begin{array}{l}\text { - } 16 \text { fully satisfied or satisfied patients }(84 \%) \\
\text { - } 2 \text { partially satisfied patients }(11 \%) \\
\text { - } 1 \text { dissatisfied patient }(5 \%)\end{array}$ \\
\hline $\begin{array}{l}\text { Darabaneau, 2008 } \\
\text { (Hyperhidrosis) }\end{array}$ & 28 & 12 & $\begin{array}{l}\text { Patients considered the surgery outcome as: } \\
\text { - Satisfactory } 24 \% \\
\text { - Good } 14,3 \% \\
\text { - Excellent } 25 \% \\
\text { - Insatisfactory } 39,3 \%\end{array}$ \\
\hline
\end{tabular}

tral axillary region, which is often the most hyperhidrotic area. The crescent type was always observed at the lateral aspect of the pectoralis muscle, suggesting that the cupped depression that exists between the muscle and the axilla interferes with a careful curet- tage. The areas around the incisions are not easily achieved by curettage, which is performed in a fan shape movement. This favors the persistence of sudoresis at these sites. The pressure that is necessary for scraping is not adequately performed around the 
cannula insertion points. From these findings, the authors suggest the performance of preoperative marking of the hyperhidrotic area through the starchiodine test, followed by the performance of a precise surgery at all identified sweating sites.

Small areas of recurrence of sweating can generally be identified with starch-iodine test. In these cases, the restricted areas can be easily excised with primary closure, avoiding a second minimally invasive procedure. ${ }^{68}$ However, Bechara et al $(2007)^{97}$ conducted a study in which they showed that liposuction-curettage can be repeated in a same patient, with effective results and without increasing the occurrence of serious complications.

Bechara et al $(2008)^{70}$ conducted a study in which they assessed the axillary blood flow of 11 patients undergoing liposuction-curettage. Patients were assessed prior to surgery and on days 1, 7 and 28 after surgery. Measurements were performed in the central region, in the area that is located at two centimeters from the center but remains inside the curetted area, and in the surrounding normal skin through laser Doppler images. On days 1 and 7 after surgery, the central area and the area at $2 \mathrm{~cm}$ from the center were significantly less perfused, while the adjacent area showed greater perfusion values. This fact could match the clinical observation that skin necrosis always occurs in the central axillary region. On day 28 after surgery, no region showed values significantly different from those obtained prior to surgery, although the central region still had slightly reduced perfusion.

Kreyden et al (2004) point out that there is no clear distinction between physiological sweating and pathological excessive sweating. The perception of hyperhidrosis, according to these authors, is very individual. ${ }^{105}$ Darabaneau et al, in a study conducted in 2008, concluded that patients with low sweating rates are not significantly clinically or psychologically benefitted by the performance of suction-curettage. ${ }^{106}$ Thus, these authors recommend a careful selection of patients, with sweating rates higher than $25 \mathrm{mg} / \mathrm{min}$ in the gravimetric test. This would avoid patient dissatisfaction. Vorkamp et al $(2010)^{10}$ believe that hyperhidrosis occurs if the sweating rate is higher than 50 $\mathrm{mg} / \mathrm{min}$. For Solish et al $(2008)^{16}$ and Hund et al (2002), hyperhidrosis takes place when sweating rates are higher than $100 \mathrm{mg} / 5$ minutes in men and 50 $\mathrm{mg} / 5$ minutes in women. ${ }^{107}$

Bechara et al (2007) propose that, for scientific studies, the effectiveness of surgical procedures for the treatment of axillary hyperhidrosis is assessed by at least one objective measuring method. ${ }^{90,108}$ They believe that the gravimetric test would be the best method for assessing surgery success. These authors report that it can be difficult to differentiate between patients in whom surgery was not effective and those who are dissatisfied, although iodine-starch and gravimetric tests are normal.

Proebstle et al (2002) believe that a control interval of at least four weeks would be necessary for the performance of the gravimetric test after the surgical procedure. This is because during the first two weeks after surgery, sweating usually stops complete$l y$, and only thereafter is restored to a new individual level. ${ }^{109}$

Swinehart et al (2000) consider that a successful outcome occurs when patients are capable of controlling their sweating by using conventional antiperspirants and deodorants, since the removal of all sweat glands is impossible. ${ }^{12}$

\section{CONCLUSION}

Suction-curettage of sweat glands is a minimally invasive surgical technique that is safe, easy to perform, has high success rates, and few side effects (Tables 1 and 2). ${ }^{100,110}$

According to the analysis of table 1, 7.47\% of patients had hematomas/seromas; $2.06 \%$ had necrosis ; and $1.47 \%$ had secondary infection. Analysis of table 2 shows that the method has an $82 \%$ success rate when used for the treatment of axillary hyperhidrosis and $92 \%$ when used for the treatment of osmidrosis. Only satisfied patients and good to excellent outcomes were considered successful results. Surgery is generally well tolerated by patients and requires shorter times away from daily activities (5-12 days), when compared to other surgical modalities.

Although the type IB techniques are usually quite effective and curative, patients who are not fully satisfied can be re-operated using the same method. This is done almost invariably with success.

The mastery of technique is crucial for the safe performance of the procedure, with few complications and low recurrence rates. Although the present results are quite satisfactory, there is always room for innovation and improvement of techniques.]

\section{ERRATUM}

There was a mistake in the publication of Chart 4 of the article "Surgical treatment of axillary hyperhidrosis by suction-curettage of sweat glands", published in journal 89(6). The topics in Chart 4 refer to Figure 3 and not Figure 2. 


\section{REFERENCES}

1. Connolly M, de Berker $\mathrm{D}$. Management of primary hyperhidrosis: a summary of the different modalities. Am J Clin Dermatol. 2003;4:681-97.

2. Gelbard CM, Epstein H, Hebert A. Primary pediatric hyperhidrosis: a review of current treatment options. Pediatr Dermatol. 2008;25:591-8.

3. Mahendiran S, Burkhart CN, Burkhart CG. Hyperhidrosis: a review of a medical condition. Open Dermatol J. 2009;3:195-7.

4. Ramos R, Moya J, Turón V, Pérez J, Villalonga R, Morera R, et al. Primary hyperhidrosis and anxiety: a prospective preoperative survey of 158 patients. Arch Bronconeumol. 2005;41:88-92.

5. Cinà CS, Clase CM. The illness intrusiveness rating scale: a measure of severity in individuals with hyperhidrosis. Qual Life Res. 1999;8:693-8.

6. Felini R, Demarchi AR, Fistarol ED, Matiello M, Delorenze LM. Prevalence of hyperhidrosis in the adult population of Blumenau-SC, Brazil. An Bras Dermatol. 2009;84:361-6.

7. Gontijo GT, Gualberto GV, Madureira NAB. Atualização no tratamento de hiperidrose axilar. Surg Cosmet Dermatol. 2011;3147-51.

8. Solish N, Bertucci V, Dansereau A, Hong HC, Lynde C, Lupin M, et al. A Comprehensive Approach to the Recognition, Diagnosis and Severity-Based Treatment of Focal Hyperhidrosis: Recommendations of the Canadian Hyperidrosis Advisory Committee. Dermatol Surg. 2007;33:908-23.

9. Hornberger J, Grimes K, Naumann M, Glaser DA, Lowe NJ, Naver H, et at Recognition, diagnosis, and treatment of primary focal hyperidrosis. J Am Acad Dermatol. 2004:51:274-86.

10. Vorkamp T, Foo FJ, Khan S, Schmitto JD, Wilson P. Hyperhidrosis: Evolving concepts and a comprehensive review. Surgeon. 2010;8:287-92.

11. Bechara FG, Tomi NS, Boorboor P, Sand M, Altmeyer P, Hoffmann K. Liposuction curettage for axillary hyperhidrosis: enhancing success rates and quantifying its efficacy. Dermatology. 2007;215:268-9.

12. Swinehart JM. Treatment of axillary hyperhidrosis: combination of the starch-iodine test with the tumescent liposuction technique. Dermatol Surg. 2000;26:392-6.

13. Larson DL. Definitive diagnosis and management of axillary hyperhidrosis: the vapometer and suction-assisted arthroscopic shaving. Aesthet Surg J. 2011;31:552-9.

14. Swartling C, Naver H, Lindberg M. Botulinum A toxin improves life quality in severe primary focal hyperhidrosis. Eur J Neurol. 2001;8:247-52.

15. Cohen JL, Cohen G, Solish N, Murray CA. Diagnosis, Impact, and Management of Focal Hyperhidrosis Treatment Review Including Botulinum Toxin Therapy. Facial Plast Surg Clin North Am. 2007;15:17-30, v-vi.

16. Solish N, Wang R, Murray CA. Evaluating the patient presenting with hyperhidrosis. Thorac Surg Clin. 2008;18:133-140.

17. Atkins JL, Butler PEM. Hyperhidrosis: A review of current management. Plast Reconstr Surg. 2002;110:222-8.

18. Coelho MS, Lira EJT, Zanin AS, Gonçalves JL, Neto NB, Pagnano PMG, et al. Video-thoracoscopic Sympathectomy for the treatment of Palmar and Axillary Hyperhidrosis. An Bras Dermatol 2002;77:171-83.

19. Macía I, Moya J, Ramos R, Rivas F, Ureña A, Rosado G, et al. Primary hyperhidrosis. Current status of surgical treatment. Cir Esp. 2010;88:146-51.

20. Stolman LP. Treatment of hyperhidrosis. Dermatol Clin. 1998;16:863-9.

21. Walling HW, Swick BL. Treatment options for hyperhidrosis Am J Clin Dermatol. 2011;12:285-95.

22. Togel B, Greve B, Raulin C. Current therapeutic strategies for hyperhidrosis: a review. Eur J Dermatol. 2002;12:219-23.

23. Hoorens I, Ongenae K. Primary focal hyperhidrosis: current treatment options and a step-by-step approach. J Eur Acad Dermatol Venereol. 2012;26:1-8.

24. Stolman LP. Hyperhidrosis: medical and surgical treatment. Eplasty. 2008;8:e22.

25. Lyra RM, Campos JRM, Kang DWW, Loureiro MP, Furian MB, Costa MG, Coelho MS. Diretrizes para a prevenção, diagnóstico e tratamento da hiperidrose compensatória. J Bras Pneumol. 2008:34:967-77.

26. Doft MA, Kasten JL, Ascherman JA. Treatment of axillary hyperhidrosis with botulinum toxin: a single surgeon's experience with 53 consecutive patients. Aesthetic Plast Surg. 2011;35:1079-86.

27. Heckmann M, Ceballos-Baumann A0, Plewig G; Hyperhidrosis Study Group. Botulinum toxin A for axillary hyperhidrosis (excessive sweating). N Engl J Med. 2001;344:488-93

28. Bechara FG, Gambichler T, Bader A, Sand M, Altmeyer P, Hoffmann K. Assessment of quality of life in patients with primary axillary hyperhidrosis before and after suction-curettage. J Am Acad Dermatol. 2007;57:207-12.

29. Naumann M, Hamm H. Treatment of axillary hyperhidrosis. $\mathrm{Br} J$ Surg 2002;89:259-61.

30. Schlereth T, Dieterich M, Birklein F. Hyperhidrosis - causes and treatment of enhanced sweating. Dtsch Arztebl Int. 2009;106:32-7.
31. Efthymiou CA, Thorpe JAC. Compensatory hyperhidrosis: a consequence of truncal sympathectomy treated by video assisted application of botulinum toxin and reoperation. Eur J Cardiothorac Surg. 2008:33:1157-8.

32. Stori Jr WS, Coelho MS, Guimarães PSF, Bergonse Neto N, Pizarro LDV. Thoracic sympathetic block by clamping for treatment of hyperhidrosis. An Bras Dermatol 2006;81:425-32.

33. Gossot D, Galetta D, Pascal A, Debrosse D, Caliandro R, Girard P, et al. "Long-term results of endoscopic thoracic sympathectomy for upper limb hyperhidrosis". Ann Thoracic Surg 2003;75:1075-9.

34. Bechara FG, Sand M, Sand D, Altmeyer P, Hoffmann K. Surgical treatment of axillary hyperidrosis: a study comparing liposuction cannulas with a suction-curettage cannula. Ann Plast Surg. 2006;56:654-7.

35. Collin J, Whatling P. Treating hyperhidrosis. Surgery and botulinum toxin are treatments of choice in severe cases. BMJ. 2000;320:1221-2.

36. Field LM. Re: Botox for a lifetime or tumescent axillary liposuction and curettage: once. Dermatol Surg. 2003;29:793-4.

37. Jemec B. Abrasio Axillae in Hyperhidrosis. Scand J Plast Reconstr Surg. 1975;9:44-6.

38. Jemec B, Holm Hansen B. Follow-up of patients operated on for axillary hyperhidrosis by subcutaneous curettage. Scand J Plast Reconstr Surg. 1978;12:65-7.

39. Rompel R, Scholz S. Subcutaneous curettage vs. injection of botulinum toxin A for treatment of axillary hyperhidrosis. J Eur Acad Dermatol Venereol. 2001;15:207-11.

40. Tofield JJ. Re: Shenaq and Spir: treatment of bilateral axillary hyperhidrosis by suction-assisted lipolysis technique. Ann Plast Surg. 1988;21:99.

41. Ou LF, Yan RS, Chen IC, Tang YW. Treatment of axillary bromhidrosis with superficial liposuction. Plast Reconstr Surg. 1998;102:1479-85.

42. Lee MR, Ryman WJ. Liposuction for axillary hyperhidrosis. Australas J Dermatol. 2005; $46: 76-9$

43. Christ JE. The application of suction-assisted lipectomy for the problem of axillary hyperhidrosis. Surg Gynecol Obstet. 1989;169:457.

44. Penna V, Iblher N, Stark BG. Histologic findings in axillary hydradenosuction. Aesthetic Plast Surg. 2007;31:16-8.

45. Payne CM, Doe PT. Liposuction for axillary hyperhidrosis. Clin Exp Dermatol. 1998;23:9-10.

46. Ichikawa K, Miyasaka M, Aikawa Y. Subcutaneous laser treatment of axillary osmidrosis: a new technique. Plast Reconstr Surg. 2006;118:170-4.

47. Goldman A, Wollina U. Subdermal Nd-YAG laser for axillary hyperhidrosis Dermatol Surg. 2008;34:756-62.

48. Yoo WM, Pae NS, Lee SJ, Roh TS, Chung S, Tark KC. Endoscopy-assisted ultrasonic surgical aspiration of axillary osmidrosis: a retrospective review of 896 consecutive patients from 1998 to 2004. J Plast Reconstr Aesthet Surg. 2006;59:978-82.

49. Commons GW, Lim AF. Treatment of axillary hyperhidrosis/bromidrosis using VASER ultrassound. Aesthetic Plast Surg. 2009;33:312-23.

50. Niiyama S, Aiba S, Katsuoka K, Ito Y, Sumiya N. Treatment of osmidrosis using the ultrasonic surgical aspirator. Acta Derm Venereol. 2006;86:238-40.

51. Park S. Very superficial ultrasound-assisted lipoplasty for the treatment of axillary osmidrosis. Aesthetic Plast Surg. 2000;24:275-9.

52. Lee HC, Chen CC, Lee WY, Chuang HU, Kao MC. Axillary hyperhidrosis and osmidrosis treated by ultrasonic surgical aspiration compared with transthoracic endoscopic sympathectomy. Surg Neurol. 2008;70:64-8.

53. Kobayashi T. Electrosurgery using insulated needles: treatment of axillary bromhidrosis and hyperhidrosis. J Dermatol Surg Oncol. 1988;14:749-52.

54. Ashby EC, Williams JL. Cryocurgery for axillary hyperhidrosis. Br Med J. 1976;2:1173-4.

55. Baumgartner FJ. Surgical approaches and techniques in the management of severe hyperhidrosis. Thorac Surg Clin. 2008;18:167-81.

56. Bisbal J, del Cacho C, Casalots J. Surgical treatment of axillary hyperhidrosis. Ann Plast Surg. 1987;18:429-36.

57. Coleman WP. Noncosmetic applications of liposuction. J Dermatol Surg Oncol. 1988:14:1085-90.

58. Breach NM. Axillary hyperhidrosis: surgical cure with aesthetic scars. Ann R Coll Surg Engl. 1979;61:295-7.

59. Cilliers PH. Surgical management of patients with hyperhidrosis. S Afr Med J. 1987;72:538-9.

60. Liu X, Mao T, Lei Z, Fan D. A simple and practical method for axillary osmidrosis resection. J Plast Reconstr Aesthet Surg. 2010;63:e420-1.

61. Qian JG, Wang XJ. Effectiveness and complications of subdermal excision of apocrine glands in 206 cases with axillary osmidrosis. J Plast Reconstr Aesthet Surg. 2010;63:1003-7.

62. Li H, Wang B, Zhang Z, Ke MS, Yang S. A refined surgical treatment modality for bromhidrosis: double $\mathrm{W}$ incision approach with tumescent technique. Dermatol Surg. 2009;35:1258-62.

63. Ellis H, Morgan MN. Surgical treatment of severe hyperhidrosis. Proc R Soc Med. 1971;64:768-70. 
64. Weaver PC. Axillary skin excision as a treatment for axillary hyperhidrosis. Postgrad Med J. 1970;46:422-4.

65. Hurley HJ, Shelley WB. A simple surgical approach to the management of axillary hyperhidrosis. JAMA. 1963;186:109-12.

66. Fan YM, Wu ZH, Li SF, Chen QX. Axillary osmidrosis treated by partial removal of the skin and subcutaneous tissue en bloc and apocrine gland subcision. Int $\mathrm{J}$ Dermatol. 2001;40:714-6.

67. Lawrence CM, Lonsdale Eccles AA. Selective sweat gland removal with minimal skin excision in the treatment of axillary hyperhidrosis: a retrospective clinical and histological review of 15 patients. Br J Dermatol. 2006;155:115-8.

68. Bechara FG, Sand M, Altmeyer P, Hoffmann K. Immunohistochemical differentiation and localization analysis of sweat glands in the adult human axilla. Plast Reconstr Surg. 2007;119:1124-5.

69. Kim IH, Seo SL, Oh CH. Minimally invasive surgery for axillary osmidrosis: combined operation with $\mathrm{CO} 2$ laser and subcutaneous tissue remover. Dermatol Surg. 1999;25:875-9.

70. Bechara FG, Sand M, Stücker M, Georgas D, Hoffmann K, Altmeyer P. Laser Doppler scanning study of axillary skin before and after liposuction curettage in patients with focal hyperhidrosis. Dermatology. 2008;216:173-9.

71. Wollina U, Köstler E, Schönlebe J, Haroske G. Tumescent suction curettage versus minimal skin resection with subcutaneous curettage of sweat glands in axillary hyperhidrosis. Dermatol Surg. 2008;34:709-16

72. Lee JC, Kuo HW, Chen CH, Juan WH, Hong HS, Yang CH. Treatment for axillary hyperhidrosis with suction-assisted cartilage shaver. $\mathrm{Br} J$ Plast Surg. 2005;58:223-7.

73. Rho NK, Shin JH, Jung CW, Park BS, Lee YT, Nam JH, Kim WS. Effects of quilting sutures on hematoma formation after liposuction with dermal curettage for treatment of axillary hyperhidrosis: a randomized clinical trial. Dermatol Surg. 2008;34:1010-5.

74. Chern E, Yau D, Chuang FC, Wu WM. Arthroscopic shaver with refinement for axillary osmidrosis. Int J Dermatol. 2010;49:813-7.

75. Arneja JS, Hayakawa TE, Singh GB, Murray KA, Turner RB, Ross LL, et al. Axillary hyperhidrosis: a 5-year review of treatment efficacy and recurrence rates using a new arthroscopic shaver technique. Plast Reconstr Surg. 2007;119:562-7.

76. Ong WC, Lim TC, Lim J, Leow M, Lee SJ. Suction-curettage: treatment for axillary hyperhidrosis and hidradenitis. Plast Reconstr Surg. 2003;111:958-9.

77. Lee D, Cho SH, Kim YC, Park JH, Lee SS, Park SW. Tumescent liposuction with dermal curettage for treatment of axillary osmidrosis and hyperhidrosis. Dermatol Surg. 2006;32:505-11

78. Bechara FG, Sand M, Hoffmann K, Boorboor P, Altmeyer P, Stuecker M. Histological and clinical findings in different surgical strategies for focal axillary hyperidrosis. Dermatol Surg. 2008;34:1001-9

79. 79. Brewer JD, Roenigk RK. Anestesia tumescente: técnica auxiliar para excisões extensas em cirurgia dermatológica. Surg Cosmet Dermatol 2010;2:140-3.

80. Wu WH. Ablation of apocrine glands with the use of a suction-assisted cartilage saver for treatment of axillary osmidrosis: na analysis of 156 cases. Ann Plast Surg. 2009;62:278-83.

81. Bieniek A, Białynicki-Birula R, Baran W, Kuniewska B, Okulewicz-Gojlik D, Szepietowski JC. Surgical treatment of axillary hyperhidrosis with liposuction equipment: risks and benefits. Acta Dermatovenerol Croat. 2005;13:212-8.

82. Qian JG, Wang XJ. Radical treatment of axillary osmidrosis by subdermal excision of apocrine glands: a prospective study in 31 cases. J Plast Reconstr Aesthet Surg. 2006;59:860-4.

83. Klein JA. Tumeescent technique for local anesthesia improves safety in large-volume liposuction. Plast Reconstr Surg. 1993;92:1085-98.

84. Rezai K. Suction curettage of the sweat glands - an update. Dermatol Surg. 2009:35:1126-9.

85. Grazer FM. A noninvasive surgical treatment of axillary hyperhidrosis. Clin Dermatol. 1992;10:357-64.

86. Seo SH, Jang BS, Oh CK, Kwon KS, Kim MBJ. Tumescent superficial liposuction with curettage for treatment of axillary bromhidrosis. J Eur Acad Dermatol Venereol. 2008;22:30-5.

87. Beer GM, Baumüller S, Zech N, Wyss P, Strasser D, Varga Z, et al. Immunohistochemical differentiation and localization analysis of sweat glands in the adult human axilla. Plast Reconstr Surg. 2006;117:2043-9.

88. Tsay RY, Lin JY. Experience of tumescent liposuction in the treatment of osmidrodis. Dermatol Surg. 2001;27:446-8

89. Park YJ1, Shin MS. What is the best method for treating osmidrosis? Ann Plast Surg. 2001;47:303-9.
90. Bechara FG, Sand M, Boorboor P, Altmeyer P, Hoffmann K. Minimally invasive surgery for the treatment of focal axillary hyperhidrosis. Plast Reconstr Surg. 2007;120:1744-5.

91. Bechara FG, Sand M, Sand D, Altmeyer P, Hoffmann K. Suction-curettage as a surgical treatment of focal axillary hyperhidrosis: recommendation for an aggressive approach. Plast Reconstr Surg. 2007;119:1390-1

92. Kim WO, Song Y, Kil HK, Yoon KB, Yoon DM. Suction-curettage with combination of two different cannulae in the treatment of axillary osmidrosis and hyperhidrosis. J Eur Acad Dermatol Venereol. 2008;22:1083-8.

93. Bechara FG, Sand M, Hoffmann K. Tumescent Liposuction with Dermal Curettage for Treatment of Axillary Osmidrosis and Hyperhidrosis - Letter to the Editor. Dermatol Surg. 2007;33:125.

94. Bechara FG, Sand M, Hoffmann K, Altmeyer P. Aggressive Shaving after Combined Liposuction and Curettage for Axillary Hyperhidrosis Leads to More Complications without Further Benefit. Dermatol Surg. 2008;34:952-3.

95. Field LM. Tumescent axillary liposuction and curettage with axillary scarring: not an important sequela. Dermatol Surg. 2003;29:317.

96. Field LM. Letter: Re: Insufficient Aggressiveness with Tumescent Suction Curettage. Dermatol Surg. 2009;35:555-6.

97. Bechara FG, Sand M, Tomi NS, Altmeyer P, Hoffmann K. Repeat liposuction-curettage treatment of axillary hyperhidrosis is safe and effective. $\mathrm{Br} \mathrm{J}$ Dermatol. 2007; 157:739-43.

98. Liu Q, Zhou Q, Song Y, Yang S, Zheng J, Ding Z. Surgical subcision as a cost-effective and minimally invasive treatment for axillary osmidrosis. J Cosmet Dermatol. 2010;9:44-9.

99. Bechara FG, Sand M, Rotterdam S, Altmeyer P, Hoffmann K. Multiple epidermal inclusion cysts after axillary liposuction-curettage: a rare complication of a frequent procedure. Int J Dermatol. 2008;47:1197-8.

100. Huang $\mathrm{YH}$, Yang $\mathrm{CH}$, Chen $\mathrm{YH}$, Chen $\mathrm{CH}$, Lee SH. Reduction in osmidrosis using a suction-assisted cartilage shaver improves the quality of life. Dermatol Surg. 2010;36:1573-7.

101. Bechara FG, Sand M, Sand D, Altmeyer P, Hoffmann K. Bilateral seroma after suction-curettage for axillary hyperhidrosis in a transaxillary breast-augmented patient. Dermatol Surg. 2007;33:731-3.

102. Rho NK, Kim BJ. Development of open comedones: a rare complication of surgery for axillary hyperhidrosis and osmidrosis. J Eur Acad Dermatol Venereol. 2008;22:401-2.

103. Bechara FG, Sand M, Sand D, Altmeyer P, Hoffmann K. Postoperative situation after axillary suction-curettage: an endoscopical view. J Plast Reconstr Aesthet Surg. 2006;59:304-6.

104. Bechara FG, Sand M, Altmeyer P. Characteristics of refractory sweating areas following minimally invasive surgery for axillary hyperhidrosis. Aesthetic Plast Surg. 2009;33:308-11.

105. Kreyden OP, Scheidegger EP. Anatomy of the sweat glands, pharmacology of botulinum toxin, and distinctive syndromes associated with hyperhidrosis. Clin Dermatol. 2004;22:40-4

106. Darabaneanu S, Darabaneanu HA, Niederberger U, Russo PA, Lischner S, Hauschild A. Long-term efficacy of subcutaneous sweat gland suction curettage for axillary hyperhidrosis: a prospective gravimetrically controlled study. Dermatol Surg. 2008;34:1170-7.

107. Hund M, Kinkelin I, Naumann M, Hamm H. Definition of axillary hyperhidrosis by gravimetric assessment. Arch Dermatol. 2002;138:539-41.

108. Bechara FG, Altmeyer P, Sand M, Hoffmann K. Surgical treatment of axillary hyperhidrosis. Br J Dermatol. 2007;156:398-9.

109. Proebstle TM, Schneiders V, Knop J. Gravimetrically controlled efficacy of subcorial curettage: a prospective study for treatment of axillary hyperhidrosis. Dermatol Surg. 2002;28:1022-6.

110. Böni R. Tumescent suction curettage in the treatment of axillary hyperidrosis: experience in 63 patientes. Dermatology. 2006;213:215-7.

MAILING ADDRESS:
Rebeca Alvares Rodrigues Maffra de Rezende
Av. Marquês de Paraná, 303
Centro
24030-210 Niterói - RJ
Brazil
E-mail: rebecamaffra@gmail.com

MAILING ADDRESS:

Rebeca Alvares Rodrigues Maffra de Rezende

Centro

24030-210 Niterói - RJ

Brazil

How to cite this article: Maffra de Rezende R, Luz FB. Surgical treatment of axillary hyperhidrosis by suction-curettage of sweat glands. An Bras Dermatol. 2014;89(6):940-54. 